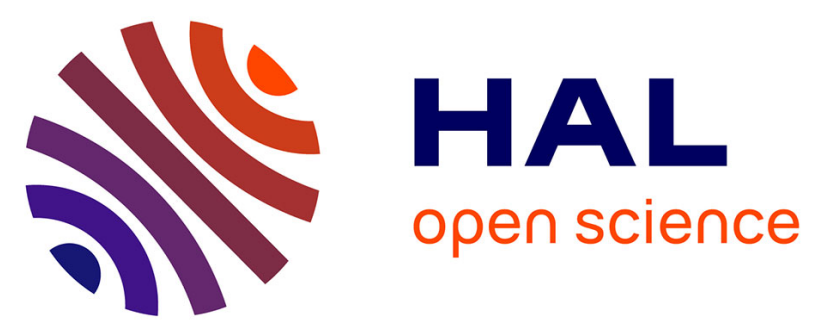

\title{
Beauty and the reef: Evaluating the use of non-expert ratings for monitoring aesthetic values of coral reefs
}

\author{
Petina Pert, Lauric Thiault, Matthew Curnock, Susanne Becken, Joachim
}

Claudet

\section{- To cite this version:}

Petina Pert, Lauric Thiault, Matthew Curnock, Susanne Becken, Joachim Claudet. Beauty and the reef: Evaluating the use of non-expert ratings for monitoring aesthetic values of coral reefs. Science of the Total Environment, 2020, 730, pp.139156. 10.1016/j.scitotenv.2020.139156 . hal-02978248

HAL Id: hal-02978248

https://hal-univ-perp.archives-ouvertes.fr/hal-02978248

Submitted on 8 Dec 2020

HAL is a multi-disciplinary open access archive for the deposit and dissemination of scientific research documents, whether they are published or not. The documents may come from teaching and research institutions in France or abroad, or from public or private research centers.
L'archive ouverte pluridisciplinaire HAL, est destinée au dépôt et à la diffusion de documents scientifiques de niveau recherche, publiés ou non, émanant des établissements d'enseignement et de recherche français ou étrangers, des laboratoires publics ou privés. 
1 Beauty and the reef: Evaluating the use of non-expert ratings for monitoring

2 aesthetic values of coral reefs.

3

4

5

6

15 Abstract

${ }^{*}$ Corresponding author - Dr Petina L. Pert, CSIRO Land and

\section{Water, Townsville, Queensland, Australia, 4811}

\section{petina.pert@csiro.auSuggested journals}

Petina L. Pert ${ }^{1 *}$, Lauric Thiault ${ }^{2}$, Matthew I. Curnock ${ }^{1}$, Nadine A. Marshall ${ }^{4}$, Joachim Claudet $^{2,3}$

1. CSIRO Land and Water, Townsville, Queensland, Australia, 4811

2. National Center for Scientific Research, PSL Université Paris, CRIOBE, USR 3278 CNRS-EPHE-UPVD, Maison des Océans, 195 rue Saint-Jacques 75005 Paris.

3. Laboratorie d'Excellence CORAIL, Moorea, French Polynesia

4. XXXX nadine.marshall00@gmail.com 
23 with aesthetic ratings. Older people and those with interest in coral reefs and who dived on the 24 reef rated photos more highly. Reporting on aesthetic values of the UNESCO Whorld Heritage

25 Sites will become increasingly as declines in their ecological state continue.

\section{Keywords}

27 Aesethetic, value, beauty, appreciation, cultural ecosystem services, attitudes, perception,

28 Great Barrier Reef 


\section{Introduction}

30 The reframing of nature by the Millennium Ecosystem Assessment report (Millennium

31 Ecosystem Assessment, 2003), in particular, as providing goods and services, has enabled a

32 mechanism by which the importance of natural places can be reconsidered (Diaz et al., 2011).

33 The aesthetic services that are provided by nature have become formally acknowledged and

34 valued, where the provision of aesthetic services is strongly related to all other cultural services

35 including recreation (Ghermandi et al., 2010; Junge et al., 2015). Areas with conditions for

36 recreation and leisure are often valuable due to their aesthetic and cultural heritage and identity

37 qualities (e.g. (Chan et al., 2012; Comberti et al., 2015; Gee and Burkhard, 2010; Jobstvogt et

38 al., 2014)). Likewise, areas with scenic beauty often provide inspiration and opportunities for

39 education, holding significant existence values (e.g., (de Oliveira and Berkes, 2014; Fletcher et

40 al., 2014; Hashimoto et al., 2014; Martínez-Pastur et al., 2015; Outeiro et al., 2015)).

41 Furthermore, De Groot et al. (2002) refers to 'aesthetic information' as an ecosystem service

42 category, provide 'scenery' as an example of an aesthetic service, and a feeling of 'enjoyment'

43 as the benefit of this service. Boyd and Banzhaf (2007) suggest that 'amenity and fulfilment' are

44 examples of aesthetic benefits and 'natural land cover in viewsheds' is the ecosystem service

45 providing the benefits. They argue this differentiation is essential in defining a workable

46 accounting system to facilitate land-use decision-making and management.

48 For the purpose of this paper, the term aesthetic value(s) has been taken as defined by Context 49 Pty Ltd (2013 p. 33), being:

“.. the response (the aesthetic response) derived from the experience of an environment or parts of an environment. Human senses - sight, touch, smell, sound, movementare important in how humans experience an environment. And culture, knowledge, 
- the characteristics of an environment

- culturally or personally derived preferences."

57 Furthermore, we have summarised the by the many contributing environmental and experiential

58 characteristics that contribute to aesthetic response, satisfaction and derived value in a natural

59 setting (Fig. 1).

\begin{tabular}{|c|c|c|}
\hline Geomorphology & \multirow{3}{*}{$\begin{array}{l}\text { Environmental } \\
\text { characteristics }\end{array}$} & \multirow{3}{*}{$\begin{array}{l}\begin{array}{l}\text { Expectations } \\
\text { (influenced by previous experience, } \\
\text { marketing \& media) }\end{array} \\
\begin{array}{l}\text { Viewpoint (position, timing } \\
\text { direction, proximity \& immersion) }\end{array} \\
\end{array}$} \\
\hline Spatial dimensions & & \\
\hline $\begin{array}{l}\text { \& visibility (through air, } \\
\text { water) }\end{array}$ & & \\
\hline $\begin{array}{l}\text { Habitat type (e.g. beach, } \\
\text { island, coral reef, mangroves) }\end{array}$ & . & \multirow{2}{*}{$\begin{array}{l}\text { Activity } \\
\text { (including use of devices that } \\
\text { augment interaction with } \\
\text { surroundings; e.g. scuba, sailboat, } \\
\text { jetski, aircraft) }\end{array}$} \\
\hline \multirow{2}{*}{$\begin{array}{l}\text { Ecosystem state } \\
\text { (health and functionality of living } \\
\text { components) }\end{array}$} & Aesthetic r & \\
\hline & satisfaction $\&$ derived value & $\begin{array}{l}\text { Sensory experience } \\
\text { (visual, auditory, olfactory, haptic) }\end{array}$ \\
\hline $\begin{array}{l}\text { Faunal presence } \\
\text { (transitory animals; e.g. birds, } \\
\text { fish, turtles, marine mammals) }\end{array}$ & 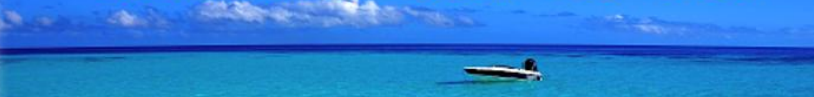 & \multirow{2}{*}{$\begin{array}{l}\text { Interpretation } \\
\text { (information accompanying the } \\
\text { place-based experience; } \text { e.g. guide } \\
\text { narratives, signage, brochures) }\end{array}$} \\
\hline \multirow{2}{*}{$\begin{array}{l}\text { Human presence } \\
\text { (including people, vessels, built } \\
\text { infrastructure and visible effects) }\end{array}$} & & \\
\hline & & $\begin{array}{l}\text { Social factors } \\
\text { (interactions with other people) }\end{array}$ \\
\hline $\begin{array}{l}\text { Season, climate \& } \\
\text { weather conditions }\end{array}$ & & $\begin{array}{l}\text { Cultural factors } \\
\text { (including normative beliefs) }\end{array}$ \\
\hline $\begin{array}{l}\text { Time of day, light \& } \\
\text { colour }\end{array}$ & & $\begin{array}{l}\text { Emotion } \\
\text { (affective responses to the myriad } \\
\text { stimuli) }\end{array}$ \\
\hline
\end{tabular}

61 Fig. 1. Characteristics and attributes that contribute to aesthetic response, satisfaction and

62 derived value in a natural setting (Great Barrier Reef context).

64 The natural beauty and aesthetic appreciation of landscapes has previously been studied in

65 various terrestrial ecosystems around the world (Arriaza et al., 2004; Beza, 2010; De Pinho et

66 al., 2014; Frank et al., 2013; Gobster et al., 2007; Hoffman and Palmer, 1996; Howley, 2011;

67 Rosley et al., 2013; Schirpke et al., 2013; Sheppard, 2004; Van den Berg et al., 1998; van der 
68 Jagt et al., 2014; van Zanten et al., 2016; Wet Tropics Management Authority, 2017; Xu et al., 69 2003), however very few studies have occurred in marine ecosystems (Fenton and Syme, 1989)

70 or more specifically within coral reefs (Dinsdale and Fenton, 2006; Fenton et al., 1998). Coral

71 reef ecosystems worldwide are significant sources of consumptive and non-consumptive

72 economic values (Wielgus et al., 2002) and supply vast numbers of people with goods and

73 services such as seafood, tourism and recreational opportunities, coastal protection, as well as

74 aesthetic and cultural benefits (Martin et al., 2016; Moberg and Folke, 1999; Werner et al.,

75 2014). Many attributes have been described as to what contributes to these non-consumptive

76 aesthetic values including the abundance of fish and corals (Dixon et al., 1993; Wilkinson, 1996;

77 Williams and Polunin, 2000), existence of iconic species/habitats (Jobstvogt et al., 2014; Levin

78 et al., 2010; Werner et al., 2014), and water clarity (Dixon et al., 1993; Hatton MacDonald et al.,

79 2015; Lee, 2017; Tosic et al., 2014; Wilkinson, 1996).

80

81 The development of indicators and quantifying the aesthetic value that people place on different

82 landscapes, seascapes, and ecosystems has been approached in a number of ways by

83 researchers over time. Primarily these have focused on using landscape assessment methods

84 which either focus on understanding experiential preferences, the physical

85 attributes/attractiveness of a place (Tardieu and Tuffery, 2019), landscape preferences, (Atauri

86 et al., 2000; de la Fuente de Val et al., 2006; de Lucio and Múgica, 1994; Huang, 2013; Múgica

87 and de Lucio, 1996), scenic quality, or the experience of the place. Two different methodological

88 approaches that assess landscape aesthetics either from an objective or a subjective point of

89 view have been established in the past (Frank et al., 2013). More recent approaches such as

90 those by Casalegno et al. (2013) and van Zanten et al. (2016) have used crowd-source

91 datasets, machine learning, (Haas et al., 2015; Seresinhe et al., 2015; Spalding et al., 2017)

92 and geo-tagged digital photographs uploaded to social media platforms to quantify and

93 objectively measure the perceived aesthetic value of ecosystems. 
95 The emergence of aesthetic values methods in the Australian heritage practice although only 96 new, is important as there is no established World Heritage methodology for assessing natural 97 beauty and aesthetic values under Criterion vii (i.e. contain superlative natural phenomena or 98 areas of exceptional natural beauty and aesthetic importance). In the Great Barrier Reef and

99 Wet Tropics World Heritage Areas in Australia attempts have been made to define and measure 100 aesthetic values (Context Pty Ltd, 2013; Wet Tropics Management Authority, 2017). More 101 recently new methods have been developed utilising non-expert visual assessments (Marshall 102 et al., 2019) and innovative technologies using artificial intelligence (Becken et al., 2018). Given

103 the importance of the tourism industry in these areas, those features and attributes that 104 currently draw visitors to these areas are important, particularly to tourism operators in the 105 areas. Furthermore, a number of values for which the Great Barrier Reef was originally 106 inscribed for are on the decline after back to back coral bleaching events recently in 2016 and 107 2017, terrestrial run-off of sediments and nutrients and associated Crown-of-Thorns Starfish 108 (COTS) (Acanthaster planci) outbreaks, acidification associated with climate change, impacts 109 from severe cyclones, and coral diseases (Brodie and Waterhouse, 2012; De'ath et al., 2012; 110 Hughes et al., 2015; Hughes et al., 2017), which have all affected the aesthetics and natural 111 beauty of some parts of the Region above and below the water (Great Barrier Reef Marine Park 112 Authority, 2019).

114 Appealing features of methods which use non-expert rating scores of aesthetic beauty include 115 simplicity and scalability, and as Marshall et al. (2019) and Haas et al. (2015) have shown, 116 relevance/correlation to environmental attributes associated with Reef health. However, before 117 such a method can be implemented and used in a management context, managers need to 118 understand the method's sensitivity, extrapolative power, and any potential biases associated 119 with non-expert visual ratings of scenes. In this study we evaluate (a) the sensitivity of rating 
120 scores used in Marshall et al. (2019) to compare underwater coral reef scenes, (b) the sampling

121 design requirements to establish appropriate confidence levels, and (c) biases associated with

122 demography and knowledge levels/expertise. 


\section{Methods}

\subsection{Study site}

125 The Great Barrier Reef (GBR) of Australia is one of the world's largest coral reef systems. It 126 houses globally-significant biodiversity, a rich diversity of underwater habitats, and a scenic 127 appeal that is universally recognised (Hughes et al., 2003). These values make it an 128 international tourism attraction: in 2013, the Great Barrier Reef received an estimated 53.3M 129 days of use, with $98 \%$ of all days comprising tourism visitation (Marshall et al., 2016). Tourism 130 operators and commercial fishers are particularly appreciative of the natural beauty of the 131 region, with the tourism industry alone worth over $\$ 5.2$ billion each year (Marshall et al., 2016).

132 It also holds immense value for local communities, where 'beautiful' is one of the first words that 133 come to local residents' minds when thinking of the GBR (Marshall et al., 2016). Residents and

134 tourists seek opportunities to appreciate the natural aesthetics of the GBR through experiences 135 such as diving and snorkelling, visiting beaches, boating and scenic flights (Marshall et al., 136 2016).

\section{$137 \quad 2.2$ Data analysis}

138 We developed a linear mixed effect model to generate expectations of how image scores were

139 related to eight covariables expected to influence the aesthetic score. These included coral size, 140 fish size, fish diversity, presence of algae, coral cover, topography, fish density, and visibility

141 (Marshall et al., 2019). Respondents and images were used as random effects. Variance 142 inflation factor (VIF) scores 3.28, indicating low collinearity among covariates. We then identified $143 \mathrm{XXXX}$ and $\mathrm{YYYY}$, defined as respondents scoring more than two standard deviations higher or 144 lower than expectations from our model, respectively. Our approach thus reveals the 
145 respondents that tend to provide more extreme scores given the general characteristics of the

146 images they evaluate. Finally, we assessed the link between socioeconomic characteristics and

147 whether a respondent was XXXX, average, or YYYY using a Fisher's exact test.

149 In order to help practitioners find a balance between low cost and high accuracy, we examined

150 how error in the image scores varied according to the number of respondents (i.e. sample size).

151 Specifically, we calculated the error (i.e. score's 95\% confidence interval) at varying sample

152 sizes ( $N=3$ to 380 respondents in increments of 2 , taken randomly without replacement from

153 the original pool of respondents). This process was repeated 100 times for each of the 181

154 images in order to calculate the median error each image add at various sample size.

155

156 Five indicators were selected that reflected distinct attributes of coral reefs: (i) coral cover; (ii)

157 coral pattern; (iii) coral topography; (iv) fish abundance; and (v) visibility (Marshall et al., 2019).

158

159 All analyses were implemented in R statistical analysis software v3.4.0.

160

161

162 


\section{Results}

164 The average aesthetic score ranged between $X$ and $X$. Four images (Fig. 2) indicate the 165 frequency and average aesthetic score.

166
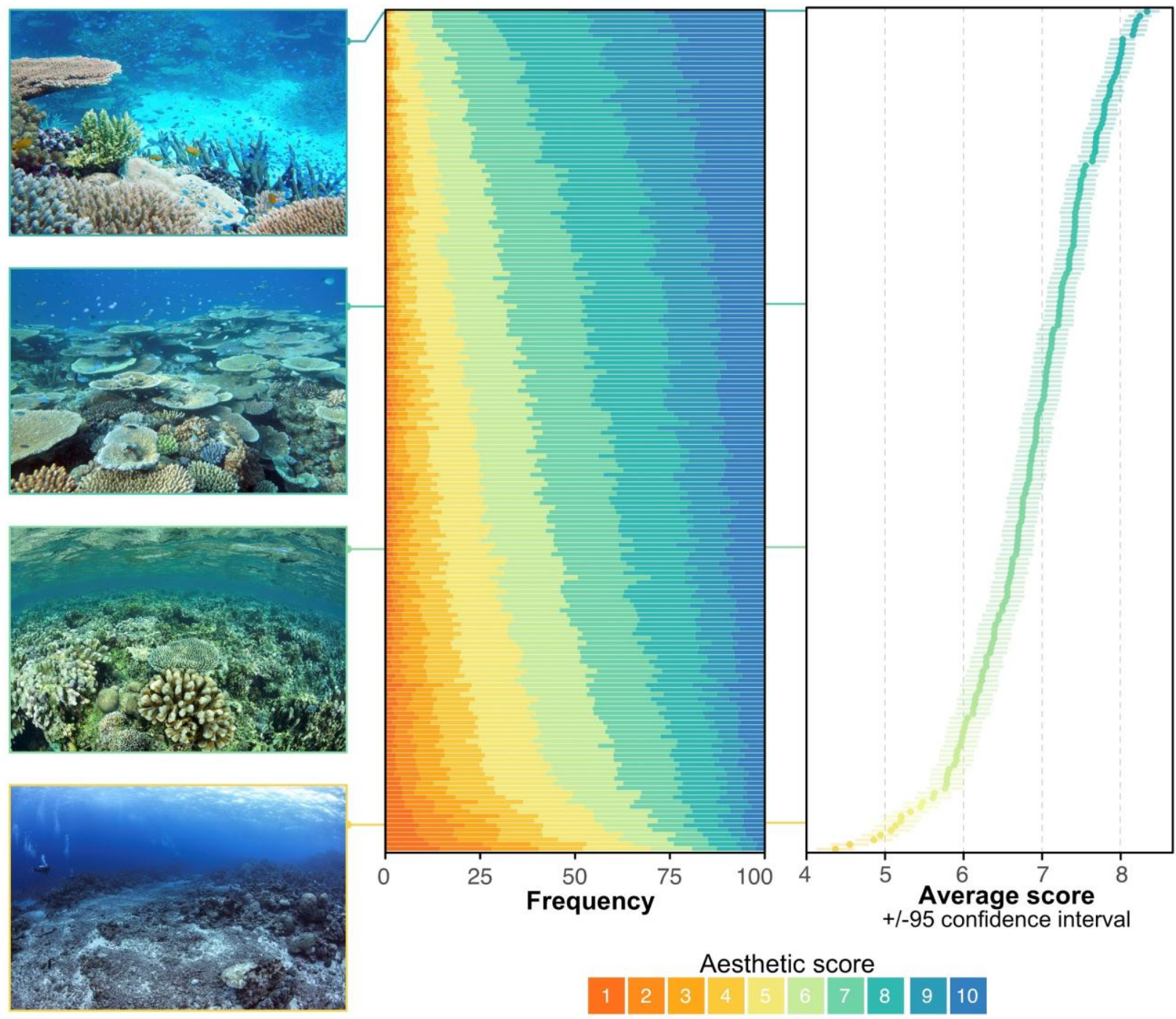

Aesthetic score

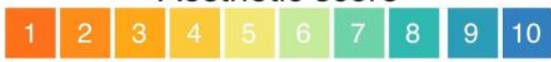

168 Fig. 2 XXXXXXXXXXXXXXXXXXX 
$2.5 \%$ systematically scored 2.91 points or lower than average
$2.5 \%$ systematically scored 2.97 points or higher than average

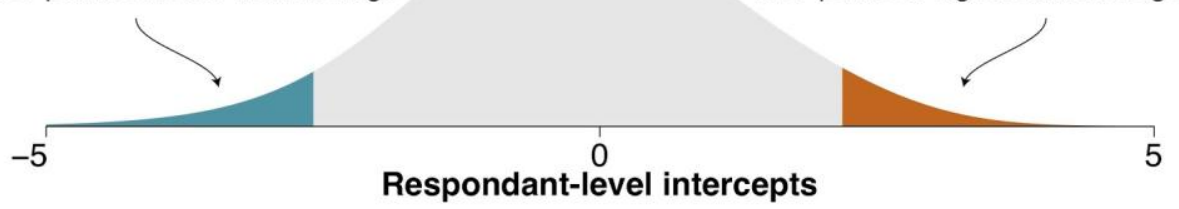

Interest

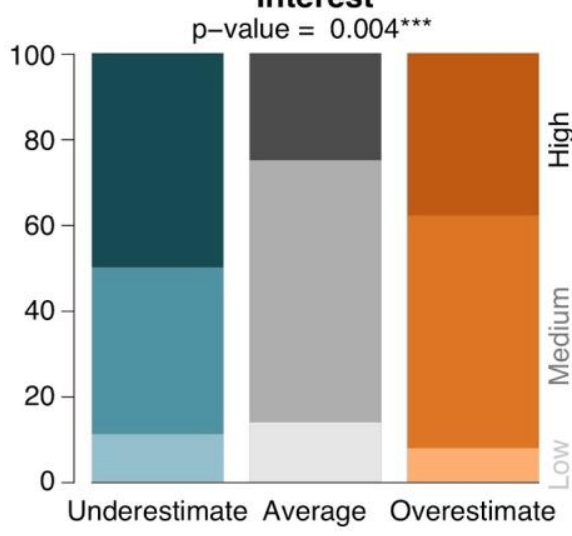

Visitation
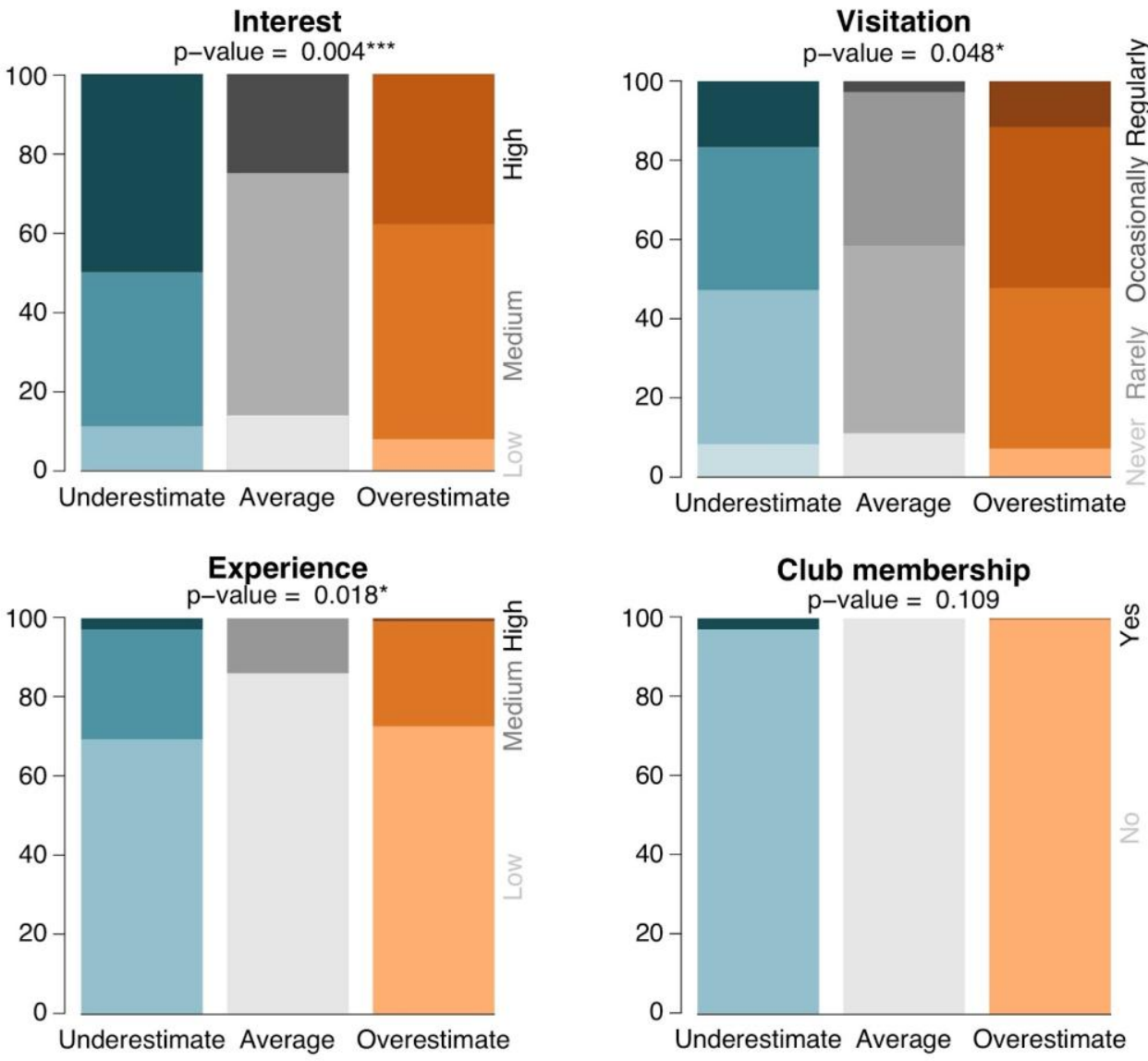

Gender $p-$ value $=0.467$

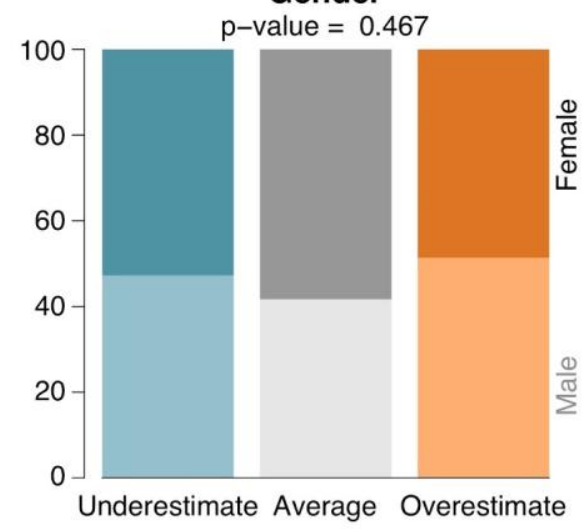

Age

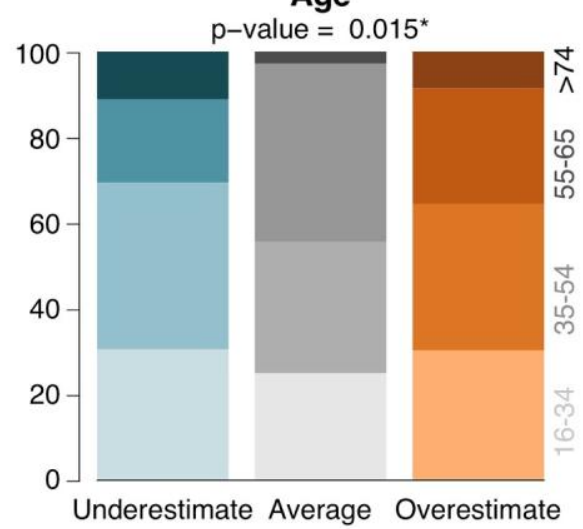

Fig. 3 XXXXXXXXXXXXXXXXXX 
171 - Have a higher level of interest in coral reefs $\left(p=0.004^{* * *}\right)$

172 - More likely to visit reef regularly $\left(p=0.048^{*}\right)$

173 - Higher self-assessed coral reef experience $\left(p=0.018^{*}\right)$

174 - Higher proportion of $>65$ 's $\left(p=0.015^{\star}\right)$

175 - No apparent prevalence of bias in either positive or negative direction

176 - While these groups inflate the error margin, they tend to cancel each other out around 177 the mean score.

178

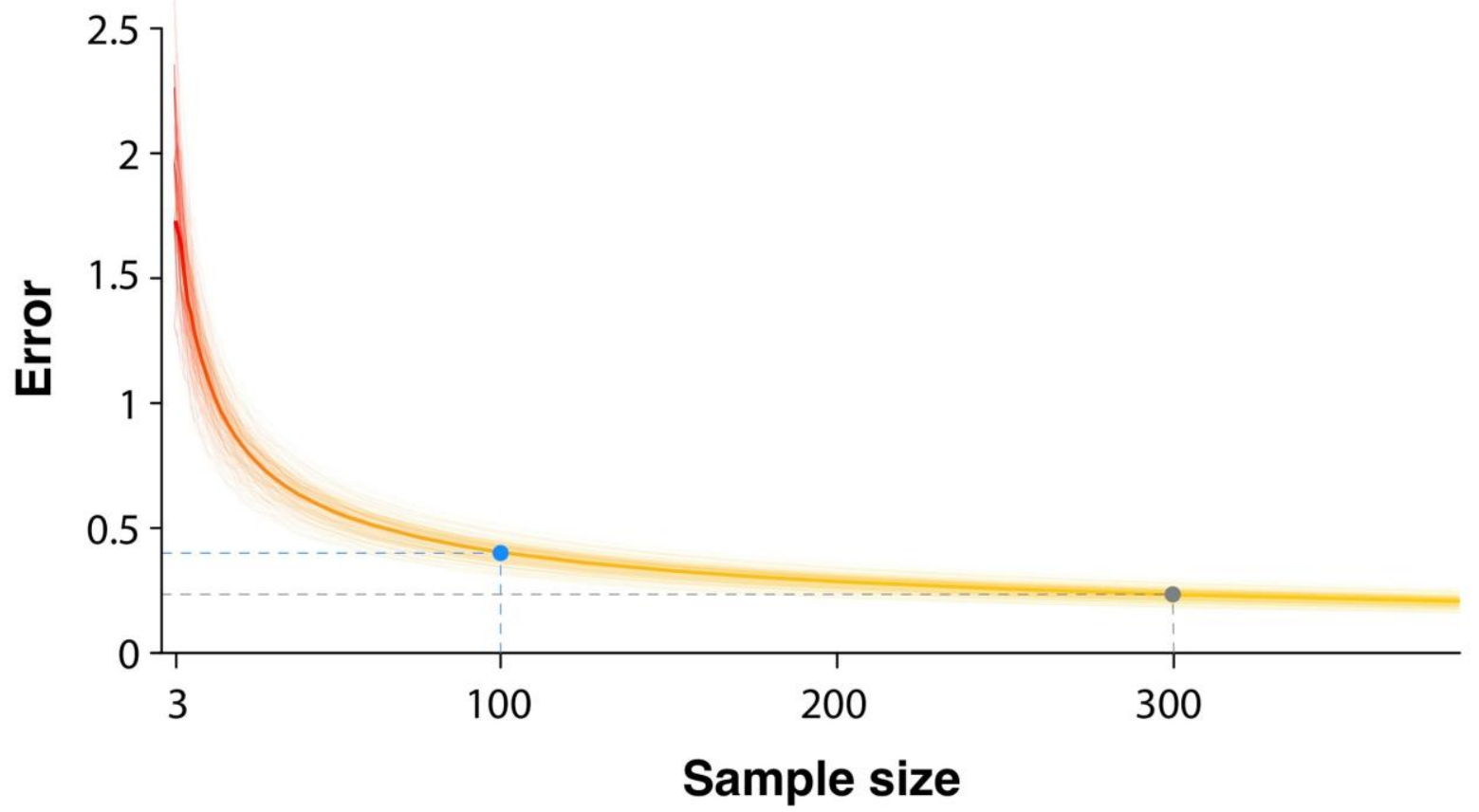

179

180 Fig. 4. Sample size describes how many people you would need to assess a photo/coral reef

181 scene, to be confident in the representativeness of the mean score and at what point do you no 182 longer change the mean response.

183 


\section{Discussion}

\section{- CHALLENGES}

Reporting through monitoring, and actively managing, aesthetic quality is potentially a critically useful strategy for natural resource managers that aim to effectively deliver both conservation and social outcomes. The advantages of monitoring aesthetic values lie essentially around the opportunity to better engage with the public, correspondingly achieving conservation (Frank et al., 2013). People appreciate and relate to aesthetics more than any other aspect of the natural environment (Marshall et al., 2018; Marshall et al., 2016; Marshall et al., 2017). Aesthetics is also a unifying value associated with natural places, whilst biodiversity is often a divisive factor 195 (Hill et al., 2016; Lecuyer et al., 2018; Schmidt and Peterson, 2009; Young et al., 2010). In the 196 case of iconic places such as the Great Barrier Reef, aesthetic values were a major factor in the 197 establishment of World Heritage Area status, and the reporting of aesthetic quality and its 198 maintenance is likely to become mandatory. For these reasons, efforts are currently underway 199 to explore how aesthetic quality might be recorded and reported on within the Great Barrier 200 Reef (NESP reference).

202 Perhaps the reason that aesthetic values have not been explicitly used by natural resource managers to further conservation goals and support is because aesthetics are seen as 204 subjective and essentially unmanageable (Context Pty Ltd, 2013; Dramstad et al., 2006). 205 However, preliminary work by the National Environment and Science Program (Becken et al., 206 2018; Marshall et al., 2019) has strongly suggested that developing indicators to rate aesthetic 207 quality is possible (Marshall et al., 2019). In sum, the development of aesthetic indicators for 208 use in specific environments such as marine environments are still very much in their infancy, 209 but the momentum supporting the development of aesthetic metrics, or indicators, is growing 
210 (Belhassen et al., 2017; Haas et al., 2015; Hein et al., 2019; Jaap, 2000; Tamayo et al., 2018;

211 Turek, 2000; Vercelloni et al., 2018; Vlami et al., 2017; Wessel et al., 2018).

213 The emerging social-ecological field continues to expand methodologies to improve techniques

214 in monitoring aesthetic heritage values, using potential indicators and computations of aesthetic

215 value. However, ongoing examination of which locations or biophysical elements are the most

216 important to the Reef's spectacular seascapes and scenery, remains an information gap.

\section{Summary of benefits}

The large size of the property and the fact that it was inscribed on the World Heritage List under all four natural criteria supports the evidence for the wide array of benefits provided by the property to the people living both within and outside the property. In addition to nature conservation and conserving cultural and wilderness values, the property provides a wide range of ecosystem services, furnishes a wealth of scientific knowledge and provides jobs through tourism, fishing, park management, research and education. Local populations can benefit from traditional, recreational and commercial fishing and hunting (some Traditional Owners continue to hunt dugong)) provided that it is sustainable. In 2011-12, recreational activities (including fishing) were the second largest direct use of the World Heritage Area, generating \$244 million (value-added), a substantial increase on the estimate of its value in 2006-07 (\$153 million). The activities generated employment equivalent of 2724 full-time jobs, up from approximately 1700 in 2006-07. Of the four recreational activities, recreational fishing is the most popular with an estimated 3.8 million fishing trips taking place in 2015-16, the expenditure generated from recreational fishing activities amounts to $\$ 70$ million. The total value of all recreational activity associated with the GBR in 2015-16 is estimated to contribute around $\$ 346$ million to the Australian economy (including $\$ 284$ million to the GBR Region). 


\section{5. Conclusion}

219 There are numerous potential management (and other) uses of aesthetic assessments and 220 monitoring with information needs that vary substantially. The rapid assessment approach is 221 potentially useful for some purpose with statistical design requirements and limitations now 222 better understood. Our findings can help World Heritage site managers better contextualise the 223 results and limitations from such monitoring and ensure that future aesthetic monitoring 224 programs can be designed to meet management and reporting needs.

225

\section{Funding}

227 This research was funded by the National Environmental Science Program (Australia). 


\section{References}

232 Arriaza, M., Cañas-Ortega, J.F., Cañas-Madueño, J.A., Ruiz-Aviles, P., 2004. Assessing the 233 visual quality of rural landscapes. Landscape and Urban Planning 69, 115-125.

234 doi:10.1016/j.landurbplan.2003.10.029

235 236

237

238

239

240

241

242

243

244

245 246
Atauri, J.A., Bravo, M.A., Ruiz, A., 2000. Visitors' landscape preferences as a tool for management of recreational use in natural areas: a case study in Sierra de Guadarrama (Madrid, Spain). Landscape Research 25, 49-62.

Becken, S., Connolly, R., Stantic, B., Scott, N., Mandal, R., Le, D., 2018. Monitoring aesethetic value of the Great Barrier Reef by using innovative technologies and artificial intelligence. , Griffith Institute for Tourism Research Report No 15. Griffith Institute for Tourism, Griffith University, Queensland.

Belhassen, Y., Rousseau, M., Tynyakov, J., Shashar, N., 2017. Evaluating the attractiveness and effectiveness of artificial coral reefs as a recreational ecosystem service. . Journal of Environmental Management 203, 448-456.

Beza, B.B., 2010. The aesthetic value of a mountain landscape: a study of the Mt. Everest Trek. Landscape and Urban Planning 97, 306-317. doi:10.1016/j.landurbplan.2010.07.003

Boyd, J., Banzhaf, S., 2007. What are ecosystem services? The need for standardized environmental accounting units. Ecological Economics 63, 616-626. 
249 Brodie, J., Waterhouse, J., 2012. A critical review of environmental management of the 'not so Great' Barrier Reef. Estuarine, Coastal and Shelf Science 104-105, 1-22. doi:10.1016/j.ecss.2012.03.012

252 Casalegno, S., Inger, R., DeSilvey, C., Gaston, K.J., 2013. Spatial covariance between aesthetic value \& other ecosystem services. PLoS ONE 8, e68437. doi:10.1371/journal.pone.0068437

Chan, K.A., Guerry, A., Balvanera, P., Klain, S., Satterfield, T., Basurto, X., Bostrom, A., Chuenpagdee, R., Gould, R., Halpern, B., Hannahs, N., Levine, J., Norton, B., Ruckelshaus, M., Russell, R., Tam, J., Woodside, U., 2012. Where are Cultural and Social in Ecosystem Services? A Framework for Constructive Engagement. BioScience 62, 744-756. doi:10.1525/bio.2012.62.8.7

Comberti, C., Thornton, T.F., de Echeverria, V.W., Patterson, T., 2015. Ecosystem services or services to ecosystems? Valuing cultivation and reciprocal relationships between humans and ecosystems. Global Environmental Change 34, 247-262. doi:10.1016/j.gloenvcha.2015.07.007

264 Context Pty Ltd, 2013. Defining the aesthetic values of the Great Barrier Reef: Final Report. 265 Context Pty Ltd, Brunswick, Victoria, p. 264.

266 De'ath, G., Fabricius, K.E., Sweatman, H., Puotinen, M., 2012. The 27-year decline of coral 267 cover on the Great Barrier Reef and its causes. Proceedings of the National Academy of 268 Sciences of the United States of America 109, 17995-17999. 
De Groot, R.S., Wilson, M.A., Boumans, R.M.J., 2002. A typology for the classification, description and valuation of ecosystem functions, goods and services. Ecological Economics 41, 393-408.

272 de la Fuente de Val, G., Atauri, J.A., de Lucio, J.V., 2006. Relationship between landscape visual attributes and spatial pattern indices: a test study in Mediterranean-climate landscapes. Landscape and Urban Planning 77, 393-407.

275 de Lucio, J.V., Múgica, M., 1994. Landscape preferences and behavior of visitors to Spanish $276 \quad$ National Parks. Landscape and Urban Planning 29, 145-160.

277 de Oliveira, L.E.C., Berkes, F., 2014. What value São Pedro's procession? Ecosystem services 278 from local people's perceptions Ecological Economics 107, 114-121.

279 doi:10.1016/j.ecolecon.2014.08.008

280 De Pinho, J.R., Grilo, C., Boone, R.B., Galvin, K.A., Snodgrass, J.G., 2014. Influence of 281 aesthetic appreciation of wildlife species on attitudes towards their conservation in Kenyan agropastoralist communities. PLoS ONE 9, e88842. doi:10.1371/journal.pone.0088842

284 Diaz, S., Quetier, F., Caceres, D.M., Trainor, S.F., Perez-Harguindeguy, N., Bret-Harte, M.S., 285 Finegan, B., Pena-Claros, M., Poorter, L., 2011. Linking functional diversity and social actor strategies in a framework for interdisciplinary analysis of nature's benefits to society. Proc Natl Acad Sci U S A 108, 895-902. doi:10.1073/pnas.1017993108 
Dinsdale, E.A., Fenton, D.M., 2006. Assessing coral reef condition: eliciting community meanings. Society \& Natural Resources 19, 239-258. doi:10.1080/08941920500460815

290 291

292 293 294

Dixon, J.A., Scura, L.F., van't Hof, T., 1993. Meeting Ecological and Economic Goals: Marine Parks in the Caribbean. Ambio 22, 117-125.

Dramstad, W.E., Tveit, M.S., Fjellstad, W.J., Fry, G.L.A., 2006. Relationships between visual landscape preferences and map-based indicators of landscape structure. Landscape and Urban Planning 78, 465-474.

Fenton, D.M., Syme, G.J., 1989. Perception and evaluation of the coastal zone: implications for coastal zone planning. Coastal Management 17, 295-308. doi:10.1080/08920758909362092

Fenton, D.M., Young, M., Johnson, V.Y., 1998. Re-presenting the great barrier reef to tourists: Implications for tourist experience and evaluation of coral reef environments. Leisure Sciences 20, 177-192. doi:10.1080/01490409809512279

Fletcher, R., Baulcomb, C., Hall, C., Hussain, S., 2014. Revealing marine cultural ecosystem services in the Black Sea. Marine Policy 50, 151-161. doi:10.1016/j.marpol.2014.05.001

Frank, S., Fürst, C., Koschke, L., Witt, A., Makeschin, F., 2013. Assessment of landscape aesthetics - Validation of a landscape metrics-based assessment by visual estimation of the scenic beauty. Ecological Indicators 32, 222-231. doi:10.1016/j.ecolind.2013.03.026 
306

Gee, K., Burkhard, B., 2010. Cultural ecosystem services in the context of offshore wind farming: A case study from the west coast of Schleswig-Holstein. Ecological Complexity 7, 349-358. doi:10.1016/j.ecocom.2010.02.008

Ghermandi, A., Nunes, P.A.L.D., Portela, R., Rao, N., Teelucksingh, S.S., 2010. Recreational, Cultural, and Aesthetic Services from Estuarine and Coastal Ecosystems. FEEM Working Paper No. 121.2009. doi:10.2139/ssrn.1532803

Gobster, P.H., Nassauer, J.I., Daniel, T.C., Fry, G., 2007. The shared landscape: what does aesthetics have to do with ecology? Landscape Ecology 22, 959-972. doi:10.1007/s10980-007-9110-x

Great Barrier Reef Marine Park Authority, 2019. Great Barrier Reef Outlook Report 2019. Great Barrier Reef Marine Park Authority, Townsville.

Haas, A.F., Guibert, M., Foerschner, A., Co, T., Calhoun, S., George, E., Hatay, M., Dinsdale, E., Sandin, S.A., Smith, J.E., Vermeij, M.J., Felts, B., Dustan, P., Salamon, P., Rohwer, F., 2015. Can we measure beauty? Computational evaluation of coral reef aesthetics. PeerJ 3, e1390. doi:10.7717/peerj.1390

Hashimoto, S., Nakamura, S., Saito, O., Kohsaka, R., Kamiyama, C., Tomiyoshi, M., Kishioka, T., 2014. Mapping and characterizing ecosystem services of social-ecological production landscapes: case study of Noto, Japan. Sustainability Science 10, 257-273. doi:10.1007/s11625-014-0285-1 
325 Hatton MacDonald, D., Ardeshiri, A., Rose, J.M., Russell, B.D., Connell, S.D., 2015. Valuing coastal water quality: Adelaide, South Australia metropolitan area. Marine Policy 52, 116-124. doi:10.1016/j.marpol.2014.11.003

Hein, M.Y., Birtles, A., Willis, B.L., Gardiner, N., Beeden, R., Marshall, N.A., 2019. Coral restoration: Socio-ecological perspectives of benefits and limitations. Biological Conservation 229, 14-25.

Hill, S.L.L., Harfoot, M., Purvis, A., Purves, D.W., Collen, B., Newbold, T., Burgess, N.D., Mace, G.M., 2016. Reconciling Biodiversity Indicators to Guide Understanding and Action. Conservation Letters 9, 450-412.

334 Hoffman, R.E., Palmer, J.F., 1996. Silviculture and forest aesthetics within stands, The New York center for forestry research and development. State University of New York, College of Environmental Sciences and Forestry, Syracuse.

Howley, P., 2011. Landscape aesthetics: Assessing the general publics' preferences towards rural landscapes. Ecological Economics 72, 161-169. doi:10.1016/j.ecolecon.2011.09.026 agrarian area becomes a tourist destination: Yilan County, Taiwan. . J. Sustain. Tour. 21, 154-171. 
Hughes, T.P., Baird, A.H., Bellwood, D.R., Card, M., Connolly, S.R., Folke, C., 2003. Climate change, human impacts, and the resilience of coral reefs. Science 301(5635), 929-933. doi:10.1126/science.1085046

Hughes, T.P., Day, J.C., Brodie, J., 2015. Securing the future of the Great Barrier Reef. Nature Climate Change 5, 508-511. doi:10.1038/nclimate2604

Hughes, T.P., Kerry, J.T., Alvarez-Noriega, M., Alvarez-Romero, J.G., Anderson, K.D., Baird, A.H., Babcock, R.C., Beger, M., Bellwood, D.R., Berkelmans, R., Bridge, T.C., Butler, I.R., Byrne, M., Cantin, N.E., Comeau, S., Connolly, S.R., Cumming, G.S., Dalton, S.J., Diaz-Pulido, G., Eakin, C.M., Figueira, W.F., Gilmour, J.P., Harrison, H.B., Heron, S.F., Hoey, A.S., Hobbs, J.A., Hoogenboom, M.O., Kennedy, E.V., Kuo, C.Y., Lough, J.M., Lowe, R.J., Liu, G., McCulloch, M.T., Malcolm, H.A., McWilliam, M.J., Pandolfi, J.M., Pears, R.J., Pratchett, M.S., Schoepf, V., Simpson, T., Skirving, W.J., Sommer, B., Torda, G., Wachenfeld, D.R., Willis, B.L., Wilson, S.K., 2017. Global warming and recurrent mass bleaching of corals. Nature 543, 373-377. doi:10.1038/nature21707

Jaap, W.C., 2000. Coral reef restoration. Ecological Engineering 15, 345-364.

Jobstvogt, N., Watson, V., Kenter, J.O., 2014. Looking below the surface: The cultural ecosystem service values of UK marine protected areas (MPAs). Ecosystem Services 10, 97-110. doi:10.1016/j.ecoser.2014.09.006

Junge, X., Schüpbach, B., Walter, T., Schmid, B., Lindemann-Matthies, P., 2015. Aesthetic quality of agricultural landscape elements in different seasonal stages in Switzerland. Landscape and Urban Planning 133, 67-77. doi:10.1016/j.landurbplan.2014.09.010 
364 Lecuyer, L., White, R.M., Schmook, B., Calme, S., 2018. Building on common ground to address biodiversity conflicts and foster collaboration in environmental management. Journal of Environmental Management 220, 217-226. doi:doi.org/10.1016/j.jenvman.2018.05.014

Lee, L.-H., 2017. Appearance's Aesthetic Appreciation to Inform Water Quality Management of Waterscapes. Journal of Water Resource and Protection 09, 1645-1659. doi:10.4236/jwarp.2017.913103

371 Levin, P.S., Damon, M., Samhouri, J.F., 2010. Developing meaningful marine ecosystem indicators in the face of a changing climate. Stanford Journal of Law, Science \& Policy 2, $36-48$.

374 Marshall, N., Marshall, P., Curnock, M., Pert, P., Smith, A., Visperas, B., 2019. Identifying indicators of aesthetics in the Great Barrier Reef for the purposes of management. PLoS One 14, e0210196. doi:10.1371/journal.pone.0210196

Marshall, N.A., Barnes, M.L., Birtles, A., Brown, K., Cinner, J.E., Curnock, M., Eakin, H., Goldberg, J., Gooch, M., Kittinger, J.N., Marshall, P., Manuel-Navarrete, D., Pelling, M., Pert, P.L., Smit, B., Tobin, R., 2018. Measuring What Matters in the Great Barrier Reef. Frontiers in Ecology and the Environment 16, 271-277.

Marshall, N.A., Bohensky, E., Curnock, M., Goldberg, J., Gooch, M., Nicotra, B., Pert, P., Scherl, L.M., Stone-Jovicich, S., Tobin, R.C., 2016. Advances in monitoring the human dimension of natural resource systems: an example from the Great Barrier Reef. 
Marshall, N.A., Curnock, M.I., Goldberg, J., Gooch, M., Marshall, P.A., Pert, P.L., Tobin, R.C., 2017. The Dependency of People on the Great Barrier Reef, Australia. Coastal Management 45, 505-518.

Martin, C.L., Momtaz, S., Gaston, T., Moltschaniwskyj, N.A., 2016. A systematic quantitative review of coastal and marine cultural ecosystem services: Current status and future research. Marine Policy 74, 25-32. doi:10.1016/j.marpol.2016.09.004

Martínez-Pastur, G., Peri, P., Lencinas, M., García-Llorente, M., Martín-López, B., 2015. Spatial patterns of cultural ecosystem services provision in Southern Patagonia. Landscape Ecology 31, 383-399. doi:10.1007/s10980-015-0254-9

Millennium Ecosystem Assessment, 2003. Ecosystems and human well-being: a framework for assessment, Washington, DC.

Moberg, F., Folke, C., 1999. Ecological goods and services of coral reef ecosystems. Ecological Economics 29, 215-233.

Múgica, M., de Lucio, J.V., 1996. The role of on-site experience on landscape preferences. A case study at Doñana National Park (Spain). Journal of Environmental Management 47, 229-239. Framing local ecological knowledge to value marine ecosystem services for the customary sea tenure of aboriginal communities in southern Chile. Ecosystem Services 16, 354-364. doi:10.1016/j.ecoser.2015.04.004 
405

406

407

408

409

410

411

412

413

414 Sheppard, S.R.J., 2004. Visual analysis of forest landscapes. Planning 44, 177-198.

415 Spalding, M., Burke, L., Wood, S.A., Ashpole, J., Hutchison, J., zu Ermgassen, P., 2017.

416

417

418 Tamayo, N.C.A., Anticamara, J.A., Acosta-Michlik, L., 2018. Estimates of Values of Philippine 419

420 421

422

Rosley, M.S.F., Lamit, H., Rahman, S.R.A., 2013. Perceiving the Aesthetic Value of the Rural Landscape Through Valid Indicators. Procedia - Social and Behavioral Sciences 85, 318-331. doi:10.1016/j.sbspro.2013.08.362

Schirpke, U., Tasser, E., Tappeiner, U., 2013. Predicting scenic beauty of mountain regions. Landscape and Urban Planning 111, 1-12. doi:10.1016/j.landurbplan.2012.11.010

Schmidt, P.M., Peterson, M.J., 2009. Biodiversity Conservation and Indigenous Land Management in the Era of Self-Determination. Conservation Biology 23, 1458-1466.

Seresinhe, C.I., Preis, T., Moat, H.S., 2015. Quantifying the Impact of Scenic Environments on Health. Sci Rep 5, 16899. doi:10.1038/srep16899 Mapping the global value and distribution of coral reef tourism. Marine Policy 82, 104113. doi:10.1016/j.marpol.2017.05.014 Reefs' Ecosystem Services. Ecological Economics 146, 633-644.

Tardieu, L., Tuffery, L., 2019. From supply to demand factors: What are the determinants of attractiveness for outdoor recreation? Ecological Economics 161, 163-175. doi:10.1016/j.ecolecon.2019.03.022 
423 Tosic, M., Narváez-Flórez, S., Parra, J.P., 2014. Selection of parameters in the design of beach 424 coastal water quality monitoring programs. Intropica 8, 43-51.

425 Turek, J.G., 2000. Science and technology needs for marine fishery habitat restoration, Oceans 2000 Mts/leee - Where Marine Science and Technology Meet, Vols 1-3, Conference Proceedings, pp. 1707-1712.

Van den Berg, A.E., Vlek, C.A., Coeterier, J.F., 1998. Group differences in the aesthetic evaluation of nature development plans: a multilevel approach. Journal of Environmental Psychology 18, 141-157 doi:0.1006/jevp.1998.0080

van der Jagt, A.P.N., Craig, T., Anable, J., Brewer, M.J., Pearson, D.G., 2014. Unearthing the picturesque: The validity of the preference matrix as a measure of landscape aesthetics. Landscape and Urban Planning 124, 1-13. doi:10.1016/j.landurbplan.2013.12.006

434 van Zanten, B.T., Van Berkel, D.B., Meentemeyer, R.K., Smith, J.W., Tieskens, K.F., Verburg, P.H., 2016. Continental-scale quantification of landscape values using social media data. Proc Natl Acad Sci U S A 113, 12974-12979. doi:10.1073/pnas.1614158113

437 Vercelloni, J., Clifford, S., Caley, M.J., Pearse, A.R., Brown, R., James, A., Christensen, B., Bednarz, T., Anthony, K., Gonzalez-Rivero, M., Mengersen, K., Peterson, E.E., 2018. Using virtual reality to estimate aesthetic values of coral reefs. R Soc Open Sci 5, 172226. doi:10.1098/rsos. 172226 
441 Vlami, V., Kokkoris, I.P., Zogaris, S., Cartalis, C., Kehayias, G., Dimopoulos, P., 2017. Cultural landscapes and attributes of "culturalness" in protected areas: An exploratory assessment in Greece. Science of the Total Environment 595, 229-243.

444 Werner, S.R., Spurgeon, J.P.G., Isaksen, G.H., Smith, J.P., Springer, N.K., Gettleson, D.A., N'Guessan, L., Dupont, J.M., 2014. Rapid prioritization of marine ecosystem services and ecosystem indicators. Marine Policy 50, 178-189. doi:10.1016/j.marpol.2014.03.020

447 Wessel, C.C., McDonald, A., Cebrian, J., 2018. An evaluative tool for rapid assessment of derelict vessel effects on coastal resources. Journal of Environmental Management 207, 262-268.

Wet Tropics Management Authority, 2017. Natural Beauty and Aesthetic Value of the Wet Tropics World Heritage Area. Wet Tropics Management Authority, Cairns.

452 Wielgus, J., Chadwick-Furman, N.E., Dubinsky, Z., Shechter, M., Zeitouni, N., 2002. DosePotential Application to the Economic Valuation of Damage. Coral Reefs 21, 253-259.

455 Wilkinson, C.R., 1996. Global Change and Coral Reefs: Impacts on Reefs, Economies and Human Cultures. Global Change Biology 2, 547-558.

457 Williams, D.W., Polunin, N.V.C., 2000. Differences between Protected and Unprotected Reefs of the Western Caribbean in Attributes Preferred by Dive Tourists. Environmental Conservation 27, 382-391. 
460 Xu, W., Lippke, B.R., Perez-Garcia, J., 2003. Valuing Biodiversity, Aesethetics, and Job Losses Associated with Ecosystem Management Using Stated Preferences. Forest Science 49, 247-257.

463 Young, J.C., Marzano, M., White, R.M., McCracken, D.I., Redpath, S.M., Carss, D.N., Quine, C.P., Watt, A.D., 2010. The emergence of biodiversity conflicts from biodiversity impacts: characteristics and management strategies. Biodiversity and Conservation 19, 3973- 